\title{
The Effect of Bacillus Coagulans as Feed Probiotics on Non-specific Immunity of Whiteleg Shrimp Litopenaeus Vannamei
}

\author{
S Supono $^{1,2}$ M Rahayu ${ }^{1}$ M W Yusuf ${ }^{1}$ \\ ${ }^{1}$ Department of Aquaculture, Universitas Lampung, Bandar Lampung, Indonesia \\ ${ }^{2}$ Post Graduate Program, Universitas Lampung, Bandar Lampung, Indonesia \\ *Corresponding author.Email :supono_unila@yahoo.com
}

\begin{abstract}
The study aimed to evaluate the effect of giving a different dosage of Bacillus coagulans to feed (feed probiotics) on nonspecific immunity of Litopenaeus vannamei (white shrimp). The parameters tested included water quality and shrimp immunity parameters, namely total hemocyte count (THC), differential hemocyte count (DHC) and phagocytosis activity (PA) and carried out for 20 days of culture. The method of administering Bacillus coagulans was by spraying it into the commercial feed. White shrimp used were the size of $13.1 \pm 0.06$ grams in the amount of 10 shrimps per container. The size of the container was $50 \mathrm{~cm} \times 40 \mathrm{~cm} \times 40 \mathrm{~cm}$ totaling 12 pieces (4 treatments and 3 replications). The treatments consisted of $\mathrm{K}$ (control), a bacterial dose of $10^{4} \mathrm{CFU} \mathrm{ml}$ ${ }^{1}$, a bacterial dose of $10^{6} \mathrm{CFU} \mathrm{ml}{ }^{-1}$, and a bacterial dose of $10^{8} \mathrm{CFU} \mathrm{ml}{ }^{-1}$. The results showed that Bacillus coagulans as a probiotic feed was able to increase the nonspecific immunity of white shrimp. The treatment of Bacillus coagulans of $10^{8} \mathrm{CFU} \mathrm{ml}{ }^{-1}$ produced the best nonspecific immunity in white shrimp.
\end{abstract}

Keywords: immunity, hemocyte, whiteleg shrimp, bacillus coagulans

\section{INTRODUCTION}

Whiteleg shrimp (Litopenaeus vannamei) is an introduction shrimp that is currently widely cultivated in Indonesia. The superiority of the white shrimp has led to higher production and demand for these shrimps [1]. The value of white shrimp exports in 2014 reached 197 thousand tons, an increase of 17.34 percent compared to the previous year [2]. Based on these data the value of white shrimp production in Indonesian fisheries has increased every year.

In line with the increased production of white shrimp, intensive cultivation systems characterized by stocking densities and high feeding have been carried out [3]. However, this intensive cultivation system can cause disease and the risk of decreased white shrimp production [4]. The disease is a major obstacle that needs attention besides feed. This causes a general attack of disease suddenly and can lead to shrimp death [5].

One effort in the prevention of disease is through enhancing the body's defense system against shrimp attack pathogens [6] by using immunostimulants [7] [8]. Shrimp body defense against disease is not only done through feed with a balanced composition but can be accompanied by giving immunostimulants in the feed. Immunostimulants are directly related to cells that can activate the immune system in shrimp [9].

Immunostimulants are now widely used for disease control in aquaculture activities as an alternative to the use of drugs, chemicals, and antibiotics [10] [11]. Immunostimulant can be applied by injection, immersion, or oral methods [12]. Giving immunostimulants through the feed is one method of immunostimulant that is widely studied in shrimp culture.

Much evidence has shown that immunostimulants added to feed can increase fish and shrimp resistance to disease infections through increased non-specific immune responses [13] [14]. In shrimp, hemocyte is a very important factor in a non-specific cellular defense system. The ability of hemocytes in the phagocytic activity that can increase in the incidence of infection shows the body's cellular defense. Increased shrimp body endurance can be known from the increased phagocytic activity of hemocyte cells [15]. 
The bacterium that has the potential to be immunostimulants is Bacillus coagulans [16] Bacillus coagulans can produce lactic acid, is resistant to high temperatures, tolerates acidic environment, is antagonistic to pathogenic bacteria, and produces anti-disease compounds [17]. Under these conditions, it is necessary to research to evaluate the use of $B$. coagulans to enhance nonspecific immunity in whiteleg shrimp.

\section{MATERIALS AND METHODS}

\subsection{Materials}

The research was conducted at the Fisheries Laboratory, Department of Fisheries and Marine, Faculty of Agriculture, University of Lampung, Indonesia. Whiteleg shrimp used were sized 13.1 \pm $0.06 \mathrm{gr}$ as many as 10 shrimps/container. Previously shrimp acclimatized for 5 days. Shrimp culture was carried out for 20 days by feeding 4 times a day at (08.00 am, 12:00 am, $4.00 \mathrm{pm}, 8.00$ $\mathrm{pm})$.

\subsection{Container Preparation}

The container for culture was the aquarium, as many as 12 units measuring $50 \mathrm{~cm} \times 40 \mathrm{~cm} \times 40$ $\mathrm{cm}$ and covered with black plastic to prevent stress on the shrimp. The aquariums were filled with seawater until it reaches the desired salinity (25 ppt) of 30 liters. Strong aeration is installed using a blower that is drained using a 0.5 -inch pipe that has been perforated and placed on the bottom of the aquarium.

Bacterium Bacillus coagulans was isolated from shrimp ponds in Lampung Province. Bacteria were prepared by the re-culture of Bacillus coagulans on $70 \%$ seawater tilted TSA (Tryptone Soy Agar) to get a younger bacterial culture. Furthermore, the bacteria were cultured on $70 \%$ seawater TSB (Tryptone Soy Broth) so that it could be stored until it was used. Bacteria were cultured on the media until they reached the desired density $\left(10^{4} \mathrm{CFU} \mathrm{ml}^{-}\right.$ ${ }^{1}, 10^{6} \mathrm{CFU} \mathrm{ml}{ }^{-1}$, and $10^{8} \mathrm{CFU} \mathrm{ml}^{-1}$ ).

\subsection{Feed Preparation}

The feed used in this study is commercial feed. The process of preparation of the test feed involved mixing the diluted bacterial isolates with a dilution dose of $10^{4} \mathrm{CFU} \mathrm{ml}{ }^{-1}, 10^{6} \mathrm{CFU} \mathrm{ml}^{-1}, 10^{8} \mathrm{CFU} \mathrm{ml}^{-1}$ and then mixed into the feed by spray technique. After being mixed evenly, the feed is dried for 5 minutes after which the feed is put into a container and ready to be given to the test shrimp by feeding it by $2 \%$ of shrimp biomass every day.

\subsection{Observed parameters}

\subsubsection{Differential hemocyte count (DHC)}

Hemocytes that have been taken from test shrimp are dripped on glass and made a review. The samples are dried in the air and fixed with $100 \%$ methanol for 5 minutes. After that, it was dried in the air again and colored by soaking it in $10 \%$ giemsa solution for 10 minutes dried in the air, washed in running water for 30 seconds and allowed to dry. The preparations were observed using a light microscope with a magnification of 40 times and distinguished according to its type namely hyaline cells and granular cells [18].

\subsubsection{Total hemocyte count (THC)}

Fresh hemocyte $(20 \mu \mathrm{L})$ was diluted with PBS (40 $\mu \mathrm{L}$ ), then samples were diluted using a micropipette and placed on the surface of the hemocytometer, then observed under a microscope. Hemocyte seen on a microscope was then calculated the number of hemocytes (total hemocyte count / THC) [18].

\subsubsection{Phagocytic activity $(P A)$}

As much as $0.1 \mathrm{ml}$ of hemocyte taken from the test shrimp was put into a microplate and then added $25 \mu \mathrm{l}$ of Staphylococcus aureus $\left(10^{6} \mathrm{CFU}\right.$ $\mathrm{ml}^{-1}$ ) mixed evenly and incubated for 20 minutes. Hemocyte as much as $5 \mu \mathrm{l}$ was dropped on a glass object and made to be prepared and then dried. The preparations were fixed into $100 \%$ methanol for 5 minutes and stained with giemsa solution for 15 minutes. Phagocytic activity was measured based on the percentage of phagocytic cells that carry out phagocytosis [18].

\subsubsection{Water quality}

Water quality parameters observed during the study included temperature, $\mathrm{pH}$, dissolved oxygen, and ammonia. Types of equipment used to control water quality were a thermometer, $\mathrm{pH}$ paper, DO meter and spectrophotometer. Media water quality was analyzed descriptively.

\subsection{Data Analysis}

Nonspecific immunity performance data were analyzed using Anova with a 95\% confidence interval using the SPSS software. If there were significant differences in the results followed by the LSD test. While the water quality data were analyzed descriptively. 


\section{RESULTS}

The results of measurements of water quality parameters such as temperature, dissolved oxygen (DO), $\mathrm{pH}$ and ammonia were still in the range of whiteleg shrimp culture to grow normally (Table 1)

Table 1. Water quality during the culture of whiteleg shrimp treatments

\begin{tabular}{|l|c|c|c|c|}
\hline & $\mathrm{K}$ & $\mathrm{A}$ & $\mathrm{B}$ & $\mathrm{C}$ \\
\hline Temperature $\left({ }^{\circ} \mathrm{c}\right)$ & 28 & 28 & 28 & 28 \\
\hline $\mathrm{DO}\left(\mathrm{ml}^{-1}\right)$ & 5.63 & 5.29 & 5.50 & 5.27 \\
\hline $\mathrm{pH}$ & 7 & 7 & 7 & 7 \\
\hline Ammonia $\left(\mathrm{ml}^{-1}\right)$ & 0.003 & 0.004 & 0.003 & 0.003 \\
\hline
\end{tabular}

\subsection{Total Hemocyte Count (THC)}

Data on total hemocyte count of white leg shrimp for 20 days of culture is displayed in Figure 1.

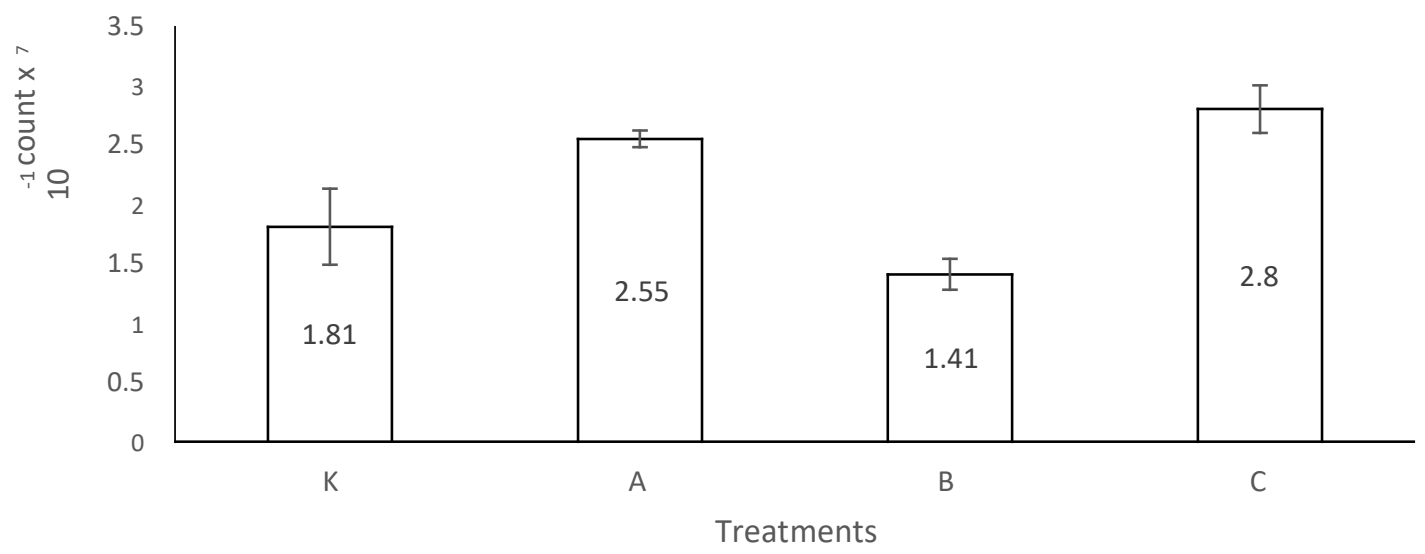

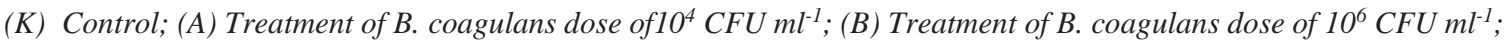
(C) Treatment of B. coagulans dose of $10^{8} \mathrm{CFU} \mathrm{ml^{-1 }}$

Figure 1 Total hemocyte count of whiteleg shrimp

Based on data analysis (Anova), the addition of $B$. coagulans to feed had a significant effect on the total hemocyte count of whiteleg shrimp at a $95 \%$ confidence level. Treatment of $B$. coagulans dose of $10^{6} \mathrm{CFU} \mathrm{ml}{ }^{-1}$ was different in the treatment of $B$. coagulans dose of $10^{4} \mathrm{CFU} \mathrm{ml^{-1 }}$, treatment of $B$. coagulans dose of $10^{8} \mathrm{CFU} \mathrm{\textrm {ml } ^ { - 1 }}$ and control. While the treatments of $B$. coagulans dose of $10^{8} \mathrm{CFU} \mathrm{ml}^{-}$ ${ }^{1}$ and treatment of $B$. coagulans dose of $10^{4} \mathrm{CFU}$ $\mathrm{ml}^{-1}$ were significantly different from the controls.

\subsection{Differential Hemocyte Count (DHC) Hyalin Cells}

Data on differential hemocyte count (DHC) of hyaline cells of whiteleg shrimp for 20 days of culture is displayed in Figure 2. Based on data analysis (Anova), the addition ofBacillus coagulans to the feed had a significant effect on the differential hemocyte count of hyaline cells of whiteleg shrimp at a $95 \%$ confidence level. Treatment of $B$. coagulans dose of $10^{8} \mathrm{CFU} \mathrm{ml} \mathrm{m}^{-1}$ was significantly different $(p<0.05)$ for all treatments. Treatment of $B$. coagulans dose of $10^{4}$ CFU ml-1 was significantlydifferent $(\mathrm{p}<0.05)$ on the treatment of B. coagulans dose of $10^{6} \mathrm{CFU}$ ml-1 and control. 




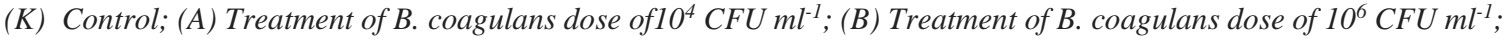
(C) Treatment of B. coagulans dose of $10^{8} \mathrm{CFU} \mathrm{ml^{-1 }}$

Figure 2 Differential hemocyte count of hyaline cells of whiteleg shrimp

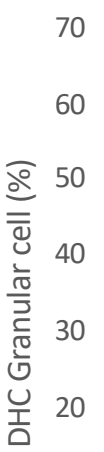

10

0

\section{6}

40
52 (1)

(K) Control; (A) Treatment of B. coagulans dose of $10^{4} \mathrm{CFU} \mathrm{ml}^{-1}$; (B) Treatment of B. coagulans dose of $10^{6} \mathrm{CFU} \mathrm{ml}^{-1}$; (C) Treatment of B. coagulans dose of $10^{8} \mathrm{CFU} \mathrm{ml}^{-1}$

Figure 3 Differential hemocyte count (DHC) of granular cells of whiteleg shrimp

While treatment of $B$. coagulans dose of $10^{6} \mathrm{CFU}$ $\mathrm{ml}^{-1}$ was not significantly different from control.

\subsection{Differential Hemocyte Count (DHC) Granular Cells}

Data on differential hemocyte count (DHC) of granular cells of whiteleg shrimp for 20 days of culture is shown in Figure 3.

Based on data analysis (Anova), the addition of Bacillus coagulans to the feed had a significant effect on DHC granular cells. Treatment of $B$. coagulans dose of $108 \mathrm{CFU}$ ml-1 treatment wassignificantly different for all treatments.
Treatment of B. coagulans dose of $10^{4} \mathrm{CFU}$ ml-1 was significantly different from the treatment of $B$. coagulans dose of $106 \mathrm{CFU} \mathrm{ml-1}$ and control.

\subsection{Phagocytosis Activity}

Data on the phagocytosis activity of whiteleg shrimp for 20 days of culture is shown in Figure 4. The results of data analysis (Anova) showed that the addition of $B$. coagulans to the feed affects the phagocytic activity of whiteleg shrimp. Treatment of B. coagulans dose of $10^{8} \mathrm{CFU} \mathrm{ml}{ }^{-1}$ was significantly different in all treatments. 


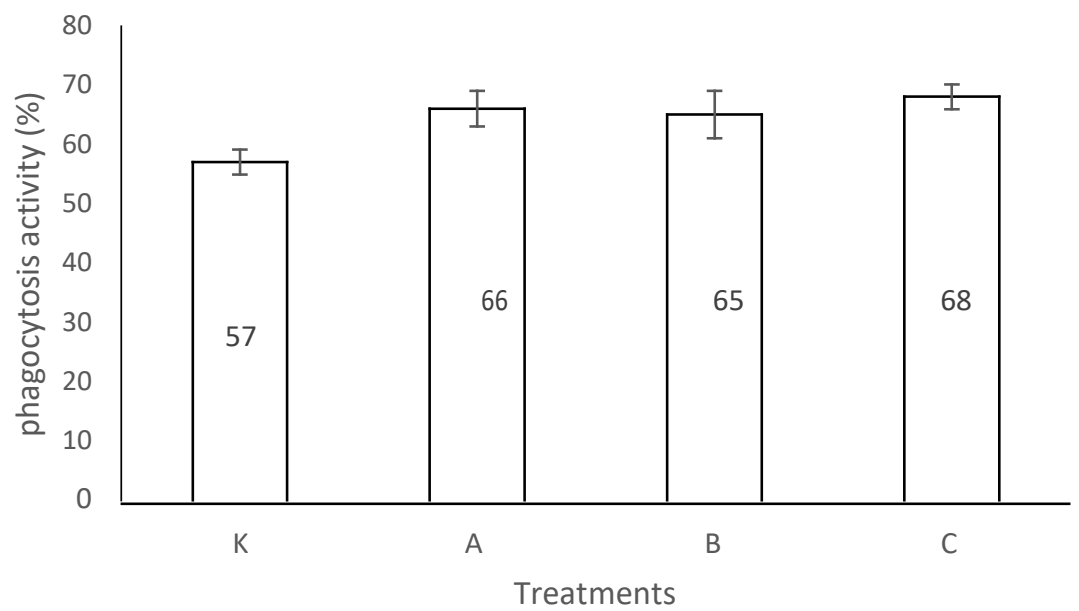

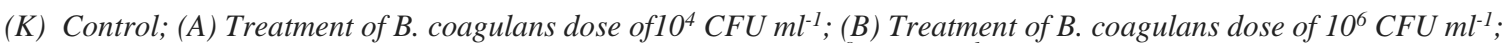
(C) Treatment of B. coagulans dose of $10^{8} \mathrm{CFU} \mathrm{ml^{-1 }}$

Figure 4 Whiteleg shrimp phagocytosis activity

However, treatment of B. coagulans dose of $10^{4}$ $\mathrm{CFU} \mathrm{ml^{-1 }}$ and treatment of $B$. coagulans dose of $10^{6} \mathrm{CFU} \mathrm{ml^{-1 }}$ did not show significantly different results on controls.

\section{DISCUSSION}

Total hemocyte count (THC), differential hemocyte count (DHC) and phagocytosis activity (AP) are immune parameters related to hemocyte used to evaluate the immunostimulatory effect of probiotics on shrimp (19). Shrimp defense mechanism depends on the hemocyte process, the total value of hemocyte obtained in this study ranges from 1.41 to $2.8 \times 10^{7} \mathrm{CFU} \mathrm{mL}^{-1}$. Total hemocyte in treatment of $B$. coagulans dose of $10^{8}$ $\mathrm{CFU} \mathrm{ml}{ }^{-1}$ was significantly different $(\mathrm{p}<0.05)$ with other treatments. Total hemocyte count obtained reached $10^{7} \mathrm{CFU} \mathrm{ml}{ }^{-1}$ so that the test shrimp was still in normal condition and even tended to increase its immunity after being given the bacterium B. coagulans. The total hemocyte count of normal shrimp is $10^{4} \mathrm{CFU} \mathrm{ml}^{-1}$ [20].

The increase in total hemocyte in this study means increasing the chances of the formation of hemocyte cells, namely hyaline cells and granular cells. Both of these cells have their respective functions. When the function of each cell increases, the shrimp can defend themselves from incoming pathogen attacks [21].

The results of DHC parameters in hyalin cells ranged from $44 \%-70 \%$ and granular cells in the range of $30 \%-56 \%$. Hyalin and granular DHC cells in the treatment of $B$. coagulans dose of $10^{8}$ CFU ml-1 were significantly different in all treatments. One of the parameters to improve the health status of shrimp with an increase in hyaline cells and granular cells, but in granular cells, the number is less than in hyaline cells [22]. Hyalin cells have an important role in the activity of phagocytosis in crustacean immunity [23].

The activity of whiteleg shrimp phagocytosis can be seen based on the increase in hemocyte cells that carry out phagocytosis [24] [25]. The mechanism of action of immunostimulants in stimulating the body's immune system is by increasing the activity of phagocyte cells [26].

As the main response mechanism in the shrimp immune system, phagocytic activity parameters indicate how much the shrimp immunity reacts to pathogens that enter the body. An increase in phagocytic activity shows that probiotic bacteria can increase phagocyte cell activity so that when an attack occurs, hemocyte cells are ready to carry out the phagocytosis process [27]. Phagocytosis itself can occur when phagocytic cells are close to the antigen, or the antigen must be attached to the surface of phagocytic cells [28]. The results of the study of phagocytosis activity showed an increase in each treatment ranging from $57 \%$ to $68 \%$. The highest value was significantly in the treatment of Bacillus coagulans dose of $10^{8} \mathrm{CFU} \mathrm{ml}^{-1}$.

\section{CONCLUSION}

The administration of $B$. coagulans with different density dosages in feed influences the nonspecific immunity of whiteleg shrimp. Bacterium B. coagulans as feed probiotic can increase total hemocyte count (THC), differential hemocyte count granular cells and phagocytocis activity. The dosage of B. coagulans $10^{8} \mathrm{CFU} \mathrm{ml}^{-1}$ on whiteleg shrimp feed showed the best results. 


\section{REFERENCES}

[1] Haryadi, Wahyu., Kurniawansyah, Rismayanti. Analisis Faktor-faktor yang mempengaruhi Pendapatan Usaha Tambak Udang Putih di Dusun Labuhan Terata Desa Labuhan Kuris Kecamatan Lape Kabupaten Sumbawa. Jurnal Ekonomi dan Bisnis. Vol.14 (2). 2017, pp. 172-186.

[2] KKP kementrian kelautan dan perikanan. Kelautan dan perikanan dalam angka 2015. Jakarta: pusat data statistik dan informasi,. 2015.

[3] Zainuddin, Haryati, Aslamyah S., Surianti. Pengaruh Level Karbohidrat dan Frekuensi Pakan terhadap Rasio Konversi Pakan dan Sintasan Juvenil Litopenaeus vannamei. Jurnal Perikanan (J. Fish. Sci.) XVI (1): 2014, pp. 29-34.

[4] Lebel L., Mungkung R., Gheewala S.H., Lebel P. Innovation cycles, niches and sustainability aquaculture industry in Thailand. Environmental Science and Policy. 13: . 2010., pp. 291-302

[5] Loy, J. D.. Infection and Immunity in the Pasific whiteleg shrimp, Litopenaeus vannamei. Dissertation. Iowa State University. Ames, Iowa., 2011.

[6] Verma A. K., Gupta S., Singh S.P., Nagpure N. S. An update on mechanism of entry of white spot syndrome virus into shrimps. Fish \& Shellfish Immunology. 67, 2017, pp. 141146.

[7] Johny F., Rroza D. K., Mahardika, Zafran, Prijono A. Penggunaan Immunostimulan untuk Meningkatkan Kekebalan Nonspesifik Benih Ikan Kerapu Lumpur, Epinephelus coiodes terhadap infeksiVirus irido. Jurnal Penelitian Perikanan Indonesia, X(5): 2005, pp.75-83.

[8] Sirirustananun N, Chen J, Lin Y., Yeh S., Liou C., Chen L., Sim S.S., Chiewa S.L. Dietary administration of a Gracilaria tenuistipitata extract enhances the immuneresponse and resistance against Vibrio alginolyticus and white spot syndromevirus in the whiteleg shrimp Litopenaeus vannamei. Fish Shellfish Immun. 31: 2011, pp. 848-855.

[9] Ekawati A. W., Nursyam H., Widjayanto E., Marsoedi. Diatomae Chaetoceros ceratosporum dalam Formula PakanMeningkatkan Respon Imun Seluler Udang Windu (Penaeus monodon Fab.) J. Exp. Life Sci. Vol. 2 No. 1.2012, pp.
[10] Jane M.S., Amar A., Amar E.C. Use of immunostimulans in shrimp culture:An update. Di dalam: Caipang CMA, Beth MI, Maningas $\mathrm{B}$, fagutao $\mathrm{FF}$, editor. Biotechnological advances in shrimp health management in the Philippines: 2015: kerala, India. Kerala (IND). Research Signpost. 2015, pp. 45-71.

[11] Karunasagar I., Kumar S.N., Maiti B., Rai P. Immunostimulation in crustaceans. Di dalam: Gudding R, Lillehaug A, Evensen $\emptyset$, editor. Fish vaccination. 2014: Oxford, United Kingdom. Oxford (UK). John Wiley \& Sons, Ltd. 2014, pp. 352-371.

[12] Manoppo H., Sukenda, Djokosetiyanto D., Fatuchri M., Harris E. Peningkatan respons imun non-spesifik, resistensi, dan pertumbuhan udang putih (Litopenaeus vannamei) melalui pemberian pakan nukleotida. Aquacultura Indonesian 10(1), 2011, pp. 1-7.

[13] Pais R., Khushiramani R., Karunasagar I. Effect of immunostimulants on hemolymph haemagglutinins of tiger shrimp Penaeus monodon. Aquac Res 38: 2008, pp. 13391345.

[14] Welker T.L., Lim C., Aksoy M.Y., Shelby R., Klesius P.H. Immune response and resistance to stress and Edwarsiella Ictaluri challenge in chennelcatfish,ictalurus punctatus, fed diet containing commercial whole-cell yeast or yeast subcomponents. J World Aquac Soc Vol.38 No. 2007, pp. 1:24-31.

[15] Putri F.M., Sarjito, Suminto. Pengaruh Penambahan Spirulina sp. dalam Pakan Buatan terhadap Jumlah Total Hemosit dan Aktivitas Fagositosis Udang Putih (Litopenaeus vannamei). Aquaculture Management and Technology Vol.2 No. 1:2013, pp. 102-112.

[16] Baron M. A Patented Strain of Bacillus Coagulans Increased Immune Response toViral Challenge. Postgraduate medicine 121 (2): 2009, pp. 114-118.

[17] Wizna A., Hafil, R., Yose D., Abdi, Kompiang P. Bacillus coagulans Potency of Forest Litter as Probiotik for Broiler. Jurnal Peternakan Indonesia 15(1):2013, pp. 75-80.

[18] Liu C.H. and Chen J.C. Effect of ammonia on the immune response of white shrimp Litopenaeus vannamei and its susceptibility to Vibrio alginolyticus. Fish and Shellfish Immunology 16: 2004, pp. 321-334. 
[19] Li C.H., Yeh S.T., Chen J.C. The immune response of whiteleg shrimp Litopenaeus vannamei following Vibrio alginolyticus injection. Fish and Shellfish Immunol 25: 2008, pp. 853-860.

[20] Bunga R and Tampangallo C S. Sitasan Benih Udang Windu yang Dipelihara dengan Beberapa Jenis Probiotik RICA dan Resistensinya terhadap Bakteri Patogen V. harveyi. Prosiding Forum Inovasi Teknologi Akuakultur, 2013, pp.863-874.

[21] Martinez S.F. The immune system of shrimp. Technical Bulletin. 2007, pp. 1:16.

[22] Johansson M., Keyser P., Sritunyalucksana K., Soderhall K. Crustacean hemocytes and haemotopoiesis. Aquaculture 191: 2000, pp. 45-52.

[23] Wang F.I. and Chen J.C. The immune respons of tiger shrimp penaeus monodon and susceptibility to Photobacterium damsela subs. damselae under temperaturestress. Aquaculture 257: 2006, pp. 34-41.

[24] Sukenda. Penggunaan Kitosan untuk Pengendalian Infeksi Vibrio harveyi pada Udang Putih (Lithopaneaus vannamei). Departemen Budidaya Perairan, Fakultas Perikanan dan Ilmu Kelautan, IPB. Jurnal
Akuakultur Indonesia, 6 (2): 2007, pp. 205209.

[25] Famelia M. P.Pengaruh Penambahan Spirulina sp. dalam Pakan Buatan Terhadap Jumlah Total Hemosit dan Aktivitas Fagositosis Udang Putih (Litopenaeus vannamei). Journal of Aquaculture Management and Technology, II (2): 2017, pp. 102-112.

[26] Yin G, Jeney G., Racs T., Xu P., JunX., Jeney Z. Effect of two Chinese herbs (Astragalus radixand Scutellaria radix) on nonspecific immune system of tilapia. Oreochromis niloticus. Aquaculture 253 :2006, pp. 39 -37.

[27] Widanarni, Sukenda. Ghita R. S. Aplikasi Sinbiotik Untuk Pencegahan Infeksi Infectious Myonecrosis Virus pada Udang Putih (Litopenaeus vannamei). Jurnal Kedokteran Hewan, 108: 2016, pp. 121-128.

[28] Resmawati M.B., Satyantini W.H., Suprapto H Pemberian Ekstrak Air Pana Spirullina platenis melalui Perendaman Terhadap Total Leukosit, Indeks Fagositosis dan Konsentrasi TNF-a Osphronemus gouramy. Jurnal Biosains Pascasarjana.Vol 18 (3).2013, pp. 